\title{
Intestinal and Pancreas Enzyme Activity of Broilers Exposed to Thermal Stress
}

Author(s)

Routman KS

Yoshida $\mathrm{L}^{1}$

Frizzas de Lima $\mathrm{AC}^{1}$

Macari $\mathrm{M}^{2}$

Pizauro Jr. JM ${ }^{1}$

1-Depto. de Tecnologia - FCAV / UNESP, Jaboticabal - SP

2-Depto. de Morfologia e Fisiologia Animal FCAV / UNESP, Jaboticabal - SP

\section{Mail Address}

João Martins Pizauro Júnior

Depto. de Tecnologia - FCAV / UNESP

Via de Acesso Prof. Paulo Donato Castellane, s/n

14884-900 - Jaboticabal - SP - Brasil

E-mail: jpizauro@fcav.unesp.br

Keywords

broilers, digestive enzymes, thermal stress

\section{Acknowledgments}

We thank Fátima A. R. Harnich for technical support during field trial and laboratorial analysis and Conselho Nacional de Desenvolvimento Científico (CNPq) for research support granted to JMPJ and MM; and for scholarship (PIBIC) granted to KSR and LY.
Arrived: January 2002

Approved: February 2003

\begin{abstract}
Thirty-two Hubbard broilers were raised under commercial husbandry to evaluate the effect of temperature exposure ( 26 and $35 \circ C)$ on the activity of digestive enzymes at different ages ( 23 and 46 days) and different diet energy levels $(2,900$ and 3,200 kcal ME/kg). Data were analyzed in a $2 \times 2 \times 2$ factorial arrangement (energy/temperature/age) in a completely randomized design. Animals were slaughtered after four hours of heat exposure for sampling of an intestinal segment, to extract alkaline phosphatase, and pancreas, to extract amylase, lipase and trypsin. The activity of intestinal alkaline phosphatase was influenced by energy level and animal age. Energy level of diet and environmental temperature interfered on the activity of pancreatic amylase. Lipase activity was affected only by broiler age. There was no effect of treatments on pancreatic trypsin activity. It was concluded that the activity of the pancreatic enzymes can be regulated by different mechanisms under stress conditions induced by heat.
\end{abstract}

\section{INTRODUCTION}

At high temperatures, birds tend to lose appetite; and feed intake, grow th rate, muscle and egg production are reduced (Dale \& Fuller, 1980; Cowans \& M ichie, 1980; Temim et al. 1999, 2000; Geraert et al., 1996) and visceral fat increases in relation to carcass weight (Temim et al., 2000; Geraert et al., 1996). Feed intake and utilization are closely related to digestion and absorption, which are in turn affected by environmental temperature changes (Owen \& Wiggs, 1971; Kitchin \& Morris, 1971; Temim et al., 2000; Bonnet et al., 1997; Itoh et al., 2001). According to Bonnett et al. (1997), when environmental temperature increased from $22^{\circ} \mathrm{C}$ to $32^{\circ} \mathrm{C}$ there was a decrease in feed efficiency from 0.485 to 0.340 in poultry, indicating that the functional digestive tract adaptation could be related to compensatory adjustment on production rate and enzymatic contents of digestive secretions (Osman \& Tanios, 1983). However, both the synthesis and the levels of pancreatic amylase, trypsin and lipase were shown to change due to diet modifications, induced by the presence of their respective substrates in gastrointestinal lumen (Brannon, 1990). Nevertheless, very few studies were related to putative thermal stress effects on the activity of digestive enzymes of poultry. The aim of this work was to evaluate alterations in the activity of intestinal alkaline phosphatase, pancreatic trypsin, amylase and lipase in birds fed diets containing two energy levels and submitted to thermal stress $\left(35^{\circ} \mathrm{C} / 4 \mathrm{~h}\right)$. 
Routman KS, Yoshida L, Frizzas de Lima AC, Macari M, Pizauro Jr. JM

\section{MATERIAL AND METHODS}

The trial was conducted using 32 male Hubbard broilers, raised according to standard commercial husbandry techniques. Enzyme activity means were analyzed in a completely randomized design and a factorial scheme $2 \times 2 \times 2$ (energy level $x$ thermal stress $x$ age).

Two corn and soybean-based diets were fed ad libitum, containing energy levels of 2,900 and $3,200 \mathrm{kcal} \mathrm{M} \mathrm{E} / \mathrm{kg}$. Starter (0-28 days) and finisher (2942 days) diets were formulated according to the appropriate nutritional requirements for birds in each phase and composition of diets is shown in Table 1.

At 23 and 46 days, four animals per treatment were submitted to thermal stress in a thermostatically controlled climate chamber (adjusted to keep environmental temperature at $35^{\circ} \mathrm{C}$ and a relative air humidity of $60 \%$ ), during four hours, without food and water. Control animals were kept in cages at room temperature of $26^{\circ} \mathrm{C}$, without food and water during the same period of time.

Immediately after heat stress, control and stressed animals were slaughtered and pancreas and intestine (duodenum, jejunum and ileum) were collected. Tissues were immediately frozen in liquid nitrogen and stored at - $70^{\circ} \mathrm{C}$ freezer for further analysis.

Pancreas was homogenized with an Ultra-Turrax in $500 \mathrm{mM}$ Tris- $\mathrm{HCl}$ buffer $(1: 20 \mathrm{w} / \mathrm{v})$ containing 50 $\mathrm{mM} \mathrm{CaCl}, \mathrm{pH} 8.0$, at $4{ }^{\circ} \mathrm{C}$. The homogenate was centrifuged at $14,000 \times \mathrm{g}$ for $30 \mathrm{~min}$, at $4{ }^{\circ} \mathrm{C}$. An aliquot of the supernatant was used for immediate lipase determination and the remaining supernatant was
Intestinal and Pancreas Enzyme Activity of Broilers Exposed to Thermal Stress

frozen in liquid nitrogen and stored at $-70{ }^{\circ} \mathrm{C}$ freezer until the activity of the other enzymes was determined.

Pancreas $\alpha$-amylase activity was measured by hydrolysis of starch followed by determination of the amount of maltose produced, in accordance to Bernfeld (1955). One unit of enzyme activity was defined and expressed as the amount of enzyme that produced one $\mu \mathrm{mol}$ of maltose $/ \mathrm{min}$, at $37^{\circ} \mathrm{C}$.

Pancreas lipase activity was assessed by titration (Tietz \& Fiereck, 1966), using as substrate the olive oil emulsion $\left(\right.$ SIGM $\left.{ }^{\circledR}\right)$ and the colipase excess extracted from poultry pancreas. One unit of enzymatic activity was defined and expressed as the quantity of enzyme that released one $\mu \mathrm{mol}$ of fatty acid per minute.

Activation of pancreas trypsinogen was accomplished by a pre-incubation period with 0.08 units of Enterokinase (SIGMA ${ }^{\circledR}$ ) for 30 minutes. After the activation, trypsin activity was determined at $37^{\circ} \mathrm{C}$ in accordance to Kakade et al. (1974) using $\mathrm{N}$ - $\alpha$-benzoylL-arginine-p-nitroanilide (L-BApNA，SIGMA ${ }^{\circledR}$ ) as substrate. One unit of enzyme activity was defined and expressed as the amount of enzyme that released one $\mathrm{mmol}$ of $\mathrm{p}$-nitroanilide/min, at $37^{\circ} \mathrm{C}$.

The intestinal mucosa was homogenized in 500 $\mathrm{mM}$ Tris- $\mathrm{HCl}$ buffer containing $50 \mathrm{mM} \mathrm{CaCl}(1: 10$ $\mathrm{w} / \mathrm{v}), \mathrm{pH} 8.0$, at $4^{\circ} \mathrm{C}$. Homogenate was centrifuged under refrigeration $\left(4^{\circ} \mathrm{C}\right)$ at $14,000 \times \mathrm{g}$ for 15 minutes. $p$-PNPPase ( $p$-nitrophenyl-phosphatase) activity of intestinal alkaline phosphatase was discontinuously determined at $37^{\circ} \mathrm{C}$, measuring the liberation of $p$-nitrophenolate ion $\left(\varepsilon=17,600 \mathrm{M}^{-1} . \mathrm{cm}^{-1}\right.$, $\mathrm{pH} 13$ ) at $410 \mathrm{~nm}$ (Pizauro et al., 1995). One unit of enzyme activity was defined and expressed as the

Table 1 - Composition of starter (1-28 d) and finisher (29-42 d) experimental diets.

\begin{tabular}{|c|c|c|c|c|}
\hline \multirow{2}{*}{$\begin{array}{l}\text { Ingredients } \\
(\%)\end{array}$} & \multicolumn{2}{|c|}{ Starter diet } & \multicolumn{2}{|c|}{ Finisher diet } \\
\hline & $2,900 \mathrm{kcal} / \mathrm{kg}$ & $3,200 \mathrm{kcal} / \mathrm{kg}$ & $2,900 \mathrm{kcal} / \mathrm{kg}$ & $3,200 \mathrm{kcal} / \mathrm{kg}$ \\
\hline Ground corn & 56.123 & 48.853 & 63.050 & 55.780 \\
\hline Soybean meal & 37.415 & 38.818 & 31.692 & 33.095 \\
\hline Soybean oil & 1.462 & 7.329 & 0.258 & 6.125 \\
\hline Premix ${ }^{1}$ & 5.000 & 5.000 & 5.000 & 5.000 \\
\hline Total & 100.000 & 100.000 & 100.000 & 100.000 \\
\hline Crude Protein (\%) & 22.260 & 22.260 & 20.250 & 20.250 \\
\hline
\end{tabular}

1- M ineral and vitamin premix, levels/kg: 176,000 IU vit. A, 40,000 IU vit. D3, $500 \mathrm{mg}$ vit. E, $100 \mathrm{mg}$ vit. K3, 36mg vit.B1, 200 mg vit. B2, $50 \mathrm{mg}$ vit. B6, $560 \mathrm{mcg}$ vit. B12, $700 \mathrm{mg}$ niacin, $3 \mathrm{mg}$ biotin, $500 \mathrm{mg}$ pantothenic acid, $30 \mathrm{mg}$ Folic acid, $20 \mathrm{~g}$ choline, $1,100 \mathrm{mg}$ iron, $300 \mathrm{mg}$ copper, $1,800 \mathrm{mg}$ manganese, $1,200 \mathrm{mg}$ zinc, $24 \mathrm{mg}$ iodine, $3 \mathrm{mg}$ sodium selenite, $20 \mathrm{~g}$ DL-methionine, $380 \mathrm{~g}$ dicalcium phosphate (304g in initial phase), calcium carbonate $176 \mathrm{~g}$ (141 g in initial phase), $36 \mathrm{~g}$ iodized salt, $2 \mathrm{~g}$ nitrovin, $10 \mathrm{~g}$ coccidicide, $200 \mathrm{mg}$ antibiotic and $1 \mathrm{~g}$ BHT. 
Routman KS, Yoshida L, Frizzas de Lima AC, Macari M, Pizauro Jr. JM
Intestinal and Pancreas Enzyme Activity of Broilers Exposed to Thermal Stress amount of enzyme that released one $\mu \mathrm{mol}$ of $p$ nitrophenolate/min, at $37^{\circ} \mathrm{C}$.

Protein content (mg/g pancreas) was determined according to Hartree (1972), using bovine soroalbumin as a standard.

\section{RESULTS AND DISCUSSION}

There was no significant interaction among the factors (energy, thermal stress and age) on the activity of the pancreas enzymes amylase, lipase and trypsin and the intestinal enzyme phosphatase alkaline. As shown in Table 2, pancreas amylase activity was affected $(p<0.05)$ by energy level of the diet and by thermal stress. Stressed birds had a higher enzymatic activity than control birds.

Details about chemical and physiological mechanisms involved in the regulation of pancreatic amylase level under normal or thermal stress conditions are still unknown. Thus, Slaughter et al. (2001) studied amylase activity in order to determine the kinetics and catalytic efficiency in relation to starch from different feedstuffs, and to establish how the enzymatic levels in gastrointestinal tract are related with glucose and insulin levels in blood. According to these authors, high levels of amylase in the gastrointestinal tract indicate that the enzymatic hydrolysis of starch could be the limiting factor in carbohydrate digestion, mainly due to factors related to its physical and chemical properties. On the other hand, Osman \& Tanios (1983) reported that thermal stress causes a consistent increase in amylase activity in broilers, which could result in a significant increase in starch hydrolysis and, consequently, in the supply of glucose for internal oxidation and posterior metabolic heat production.
Thus, high pancreatic amylase activity indicates that pancreas plays an important role in the regulation of the levels of intestinal amylase and glucose supplied to achieve energetic requirements under heat stress conditions. Furthermore, higher pancreatic amylase activity in response to an increase in environmental temperature suggests that the levels of pancreatic amylase could be regulated by a complex interaction among paracrine and endocrine pancreatic secretions and neuroendocrine stimuli that could explain the abdominal fat deposition in animals exposed to chronic heat stress.

Pinchasov et al. (1990) studied digestive enzymes in birds aged 14 to 83 days and fed ad libitum or intermittently. Pancreas amylase levels were reported to increase with age. These authors did not find an age effect on lipase and trypsin activities when these enzymes were expressed in units/g pancreas. Nevertheless, when the results were expressed in units/g body weight, a difference was seen between 20 and 33 days of age in the birds fed intermittently.

According to Table 2, different treatments (diet energy level, heat stress and age) did not result in different trypsin activities. Similar results were observed by Pinchasov et al. (1990) for trypsin activity in poultry from 14 to 83 days of age.

In relation to lipase activity, the results suggested that energy levels of 2,900 and $3,200 \mathrm{kcal} \mathrm{M} \mathrm{E} / \mathrm{kg}$ were not enough to detect effects of added fat in diet. It has been suggested that the amount and type of triglycerides in the diet regulate pancreatic lipase activity but the mechanism is still unclear (Ricketts \& Brannon, 1994). Other studies have shown that different fat levels added to the diet rapidly resulted in adaptive changes that reached a plateau in five days (Deschodt-Lanckman et al., 1971).

Alkaline phosphatase activity was affected by diet

Table 2 - Effect of thermal stress and dietary energy level on intestinal alkaline phosphatase (AP), pancreatic lipase (L), trypsin (T) and amylase $(A)$ extracted from poultry.

\begin{tabular}{|c|c|c|c|c|c|c|c|c|c|}
\hline \multirow{2}{*}{$\begin{array}{l}\text { Sources of } \\
\text { variation }\end{array}$} & \multicolumn{2}{|c|}{ Energy (kcal ME/kg) } & \multirow[b]{2}{*}{ P value } & \multicolumn{2}{|c|}{ Stress } & \multirow[b]{2}{*}{$P$ value } & \multicolumn{2}{|c|}{ Age (days) } & \multirow[b]{2}{*}{ P value } \\
\hline & 2,900 & 3,200 & & Yes & No & & 23 & 46 & \\
\hline $\mathrm{AP}(\mathrm{U} / \mathrm{mg} \text { protein })^{1}$ & 477.90 & 391.15 & $*$ & 419.03 & 450.02 & NS & 508.91 & 360.14 & $* *$ \\
\hline L(U/mg protein) & 14.56 & 12.48 & NS & 13.53 & 13.51 & NS & 16.85 & 10.19 & $* *$ \\
\hline $\mathrm{T}(\mathrm{U} / \mathrm{mg}$ protein) & 35.83 & 34.71 & NS & 37.90 & 32.63 & NS & 38.54 & 31.99 & NS \\
\hline $\mathrm{A}(\mathrm{U} / \mathrm{mg}$ protein) & 217.65 & 146.16 & $* *$ & 200.38 & 163.43 & $*$ & 184.73 & 179.08 & NS \\
\hline
\end{tabular}

1- Statistical difference between means in the lines for each treatment

NS - non significant, $p>0.05$;

$* p<0.05$

$* * p<0.01$ 
energy and animal age; it was higher $(p<0.05)$ in animals fed the diet containing 2,900kcal M E/ $/ \mathrm{kg}$ and at 23 days of age. There was no effect of environmental temperature $(p>0.05)$ on alkaline phosphatase activity. Considering that alkaline phosphatase activity could be modified by several factors (Komada et al., 1989), the results obtained in the current work suggest that alkaline phosphatase activity extracted from broiler gut is influenced by dietary energy level. In rats, contrasting results were found; alkaline phosphatase activity increased immediately after the rats were fed a meal rich in fat (Alpers et al., 1995). Thus, it seems reasonable to accept that these differences were originated by species characteristics, tissues and/or different methods used to prepare the enzymatic substrate, besides other unknown factors.

\section{CONCLUSIONS}

Pancreas amylase activity was affected by dietary energy level and thermal stress conditioning. There was no difference among treatments on pancreatic trypsin and lipase activity. Dietary energy level and animal age affected intestinal phosphatase alkaline activity and there was no effect of thermal stress on this enzyme.

The findings of this study suggest that the activity of pancreas amylase, lipase and trypsin, in animals under thermal stress, could be regulated by different mechanisms. How ever, it is still unclear if these changes are essential for poultry to better use carbohydrates, lipids and proteins under thermal stress conditions.

\section{REFERENCES}

Alpers DH, Zhang Y, Ahnen J. Synthesis and parallel secretion of rat intestinal alkaline phosphatase and surfactant-like particle protein. American Journal of Physiology 1995; 268(E): 1205-14.

Bernfeld P. Amylases a and b. In: M ethods in Enzymology. ed. by Colowick SB and Kaplan NO. New York: Academic Press, 1955. Vol.1,pp. 49-53.

Bonnet S, Geraert PA, Lessire M, Carre B, Guillaumin S. Effect of high ambient temperature on feed digestibility in broiler. Poultry Science 1997; 76(6): 857-63.

Brannon PM . Adaptation of the exocrine pancreas to diet. Annual Review of Nutrition 1990; 10: 88-105.

Cowans PJ, Michie W. Increasing the environmental temperature later in lay and performance of the fowl. British Poultry Science 1980; 21: 339-43.

Dale NM, Fuller HL. Effect of diet composition on feed intake and growth of chicks under heat stress. II. Constant vs. cycling temperatures. Poultry Science 1980; 59: 1434-41.

Deschodt-Lanckman M, Robberecht P, Camus J, Christophe J. Shortterm adaptation of pancreatic hydrolases to nutritional and physiological stimuli in adult rats. Biochimie (Paris) 1971; 53: 789-96.

Geraert PA, Padilha JC, Guillaumin S. M etabolic and endocrine changes induced by chronic heat exposure in broiler chickens: growth performance, body composition and energy retention. British Journal of Nutrition 1996; 75(2): 195-204.

Hartree EF. Determination of protein: a modification of the Lowry method that gives a linear photometric response. Analytical Biochemistry 1972; 48: 422-27.

Itoh F, Hodate K, Koyama S, Rose MT, M atsumoto M, Ozawa A, Obara $Y$. Effects of heat exposure on adrenergic modulation of insulin and glucagon secretion in sheep. Endocrinology Journal 2001; 48(2): 193-98.

Kakade ML, Rackis JJ, M cGhee JG. Determination of trypsin inhibitor activity of soy products. A collaborative analysis of on improved procedure. Cereal Chemistry 1974; 51: 376-82.

Kitchin SE, M orris D. The effect of acclimation temperature on amino acid transport in the goldfish intestine. Comparative Biochemistry and Physiology 1971; 40A: 431-43.

Komada T, Koyama I, Arai Y, Sekine T, Sakagishi $Y$, Kumegawa $M$, Alpers DH. Rat ileal phosphatase activity and secretion is stimulated by alterations in calcium metabolism. Biochemistry Biophysic Acta 1989; 90: 165-74.

Osman AM, Tanios NI. The effect of heat on the intestinal and pancreatic levels of amylase and maltase of laying hens and broilers. Comparative Biochemistry and Physiology 1983; 75A: 563-7.

Owen TG, Wiggs AJ. Thermal compensation in the stomach of the brook trout. Comparative Biochemistry and Physiology 1971; 40A: 465-73.

Pinchasov Y, Nir I, Nitsan Z. M etabolic and anatomical adaptations of heavy-bodied chicks to intermitent feeding. 2. Pancreatic digestive enzymes. British Poultry Science 1990; 31: 769-77.

Pizauro Jr JM, Ciancaglini P, Leone FA. Characterization of the phosphatidylinositol-specific phospholipase C-released form of rat osseous plate alkaline phosphatase and its possible significance on endochondral ossification. M olecular and Cellular Biochemistry 1995; 152: 121-29.

Ricketts J, Brannon PM. Amount and type of dietary fat regulate pancreatic lipase gene expression in rats. Journal of Nutrition 1994; 124: 1166-71.

Slaughter SL, Ellis PR, Butterworth PJ. An investigation of the action of porcine pancreatic alpha-amylase on native and gelatinised starches. Biochimic et Biophysica Acta 2001; 1525(1-2): 29-36.

Temim S, Chagneau AM, Guillaumin S, M ichel J, Peresson R, Geraert PA, Tesseraud S. Effects of chronic heat exposure and protein intake 
on growth performance, nitrogen retention and muscle development in broiler chickens. Reproduction Nutrition Development 1999; 39(1): 145-156.

Temim S, Chagneau AM, Guillaumin S, Michel J, Peresson R, Tesseraud S. Does excess dietary protein improve growth performance and carcass characteristics in heat-exposed chickens? Poultry Science 2000; 79(3): 312-17.

Tietz NW, Fiereck EA. A specific method for serum lipase determination. Clinica Chimica Acta 1966; 13: 352-59. 